Max-Planck-Institut für demografische Forschung

Max Planck Institute for Demographic Research

Konrad-Zuse-Strasse 1 - D-18057 Rostock - GERMANY

Tel +49 (0) 3812081 - 0; Fax +49 (0) 3812081 - 202;

http://www.demogr.mpg.de

MPIDR WORKING PAPER WP 2010-011

FEBRUARY 2010 (REVISED MARCH 2015)

\title{
Harmonized Histories
}

\section{Manual for the Preparation of}

Comparative Fertility and Union Histories

(as part of the Nonmarital Childbearing Project)

Brienna Perelli-Harris

Michaela Kreyenfeld (kreyenfeld@demogr.mpg.de)

Karolin Kubisch (kubisch@demogr.mpg.de)

(C) Copyright is held by the authors.

Working papers of the Max Planck Institute for Demographic Research receive only limited review. Views or opinions expressed in working papers are attributable to the authors and do not necessarily reflect those of the Institute. 


\title{
Harmonized Histories
}

\section{Manual for the Preparation of Comparative Fertility and Union Histories (as part of the Nonmarital Childbearing Project)}

Brienna Perelli-Harris, Michaela Kreyenfeld, Karolin Kubisch, Wendy Sigle-Rushton, Renske Keizer, Paola DiGiulio, and other members of the Nonmarital Childbearing Network

\begin{abstract}
:
This document describes the standardization process of the Harmonized Histories. The Harmonized Histories is a comparative database of rich reproductive and union histories from surveys conducted in a number of countries in Europe. Given that birth and union data has been collected in a number of ways in different surveys, it has been very difficult to conduct cross-national analyses of recent union and fertility behavior over time. A team of researchers called the Nonmarital Childbearing Network has cleaned and standardized the surveys according to guidelines set out in this manual. Currently, the database includes data from the Generations and Gender Surveys (GGSs) of Austria, Belgium, Bulgaria, Estonia, France, Germany, Hungary, Italy, Norway, Romania, and Russia; the 2003 Dutch Fertility and Family Survey; the British Household Panel Survey; the Polish Employment, Family and Education Survey; the Spanish Survey of Fertility and Values; the Swiss Household and the National Survey of Family Growth 1995 and 2007 for the USA.
\end{abstract}

Keywords: Fertility, marriage, partnership, data

Version 11.0 (March. 2015) 


\section{Table of Contents}

1 Introduction ................................................................................................................ 3

2 General Considerations ................................................................................. 3

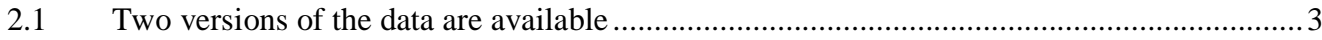

2.2 General set up of data (single record data) ............................................................ 4

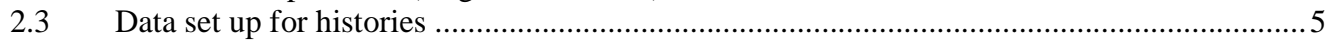

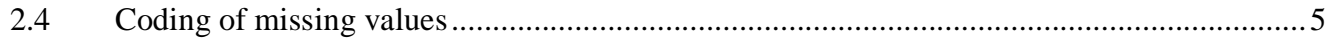

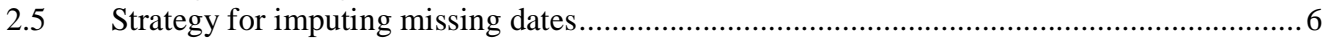

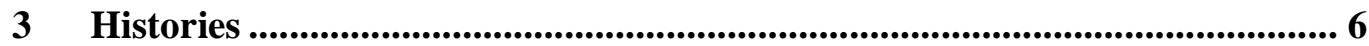

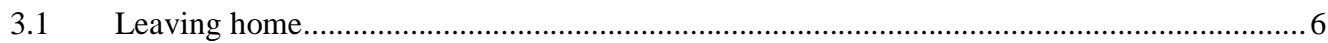

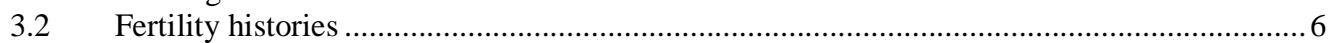

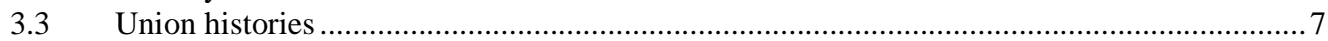

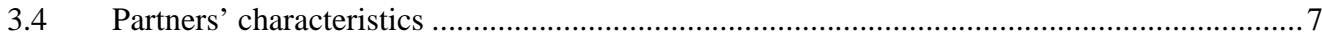

4 Background variables................................................................................. 8

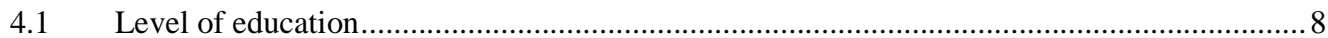

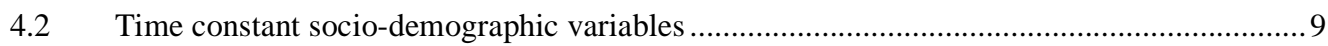

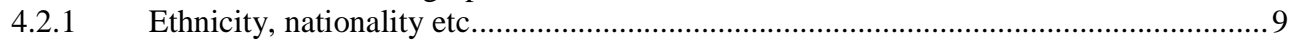

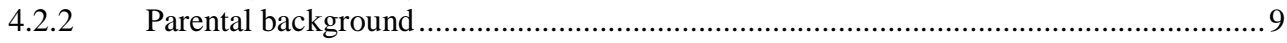

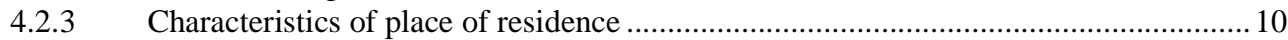

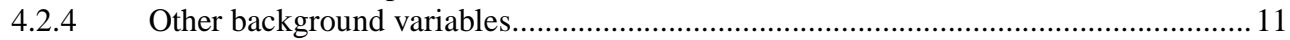

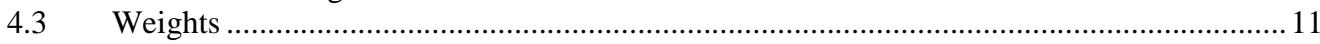

5 Country Specific Considerations/Coding.......................................................12

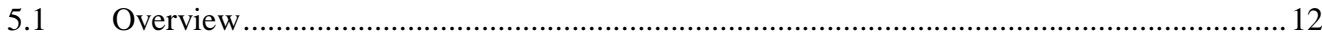

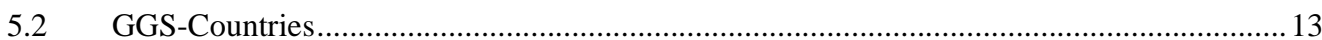

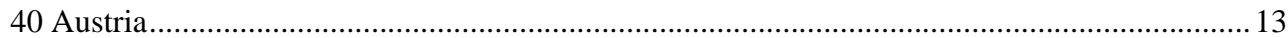

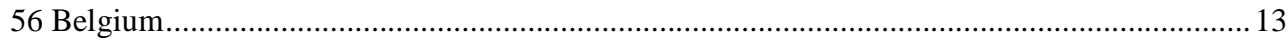

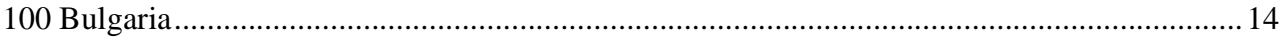

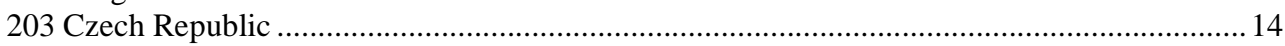

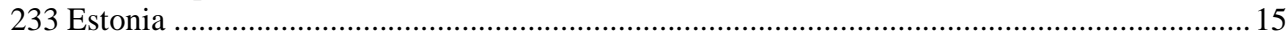

250 France

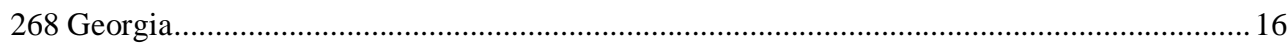

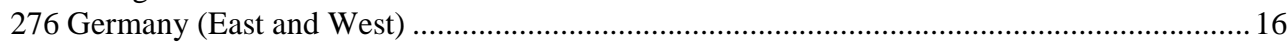

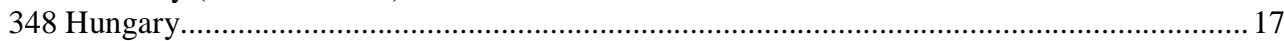

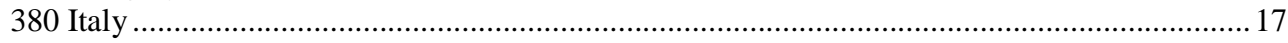

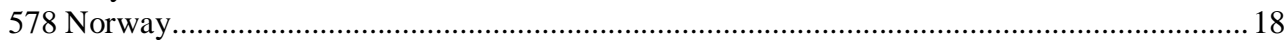

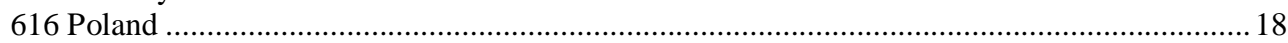

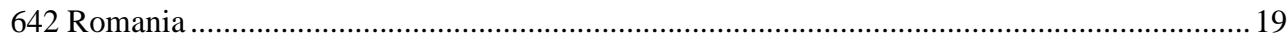

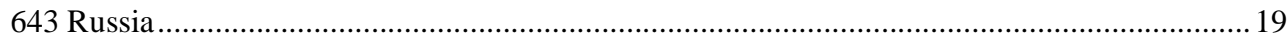

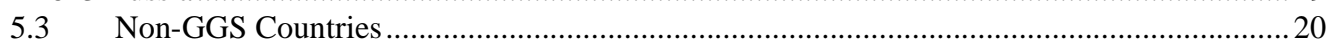

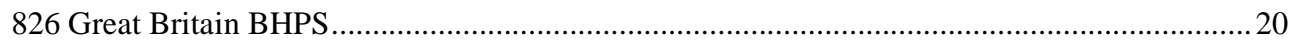

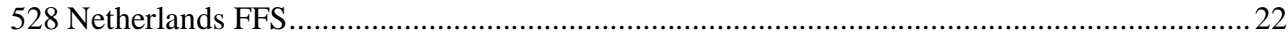

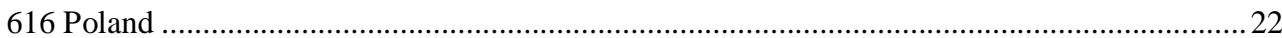

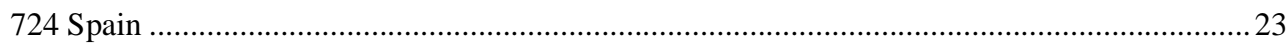

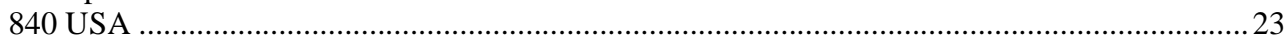

References....................................................................................................................24

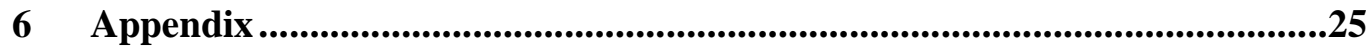

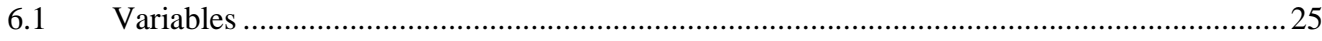

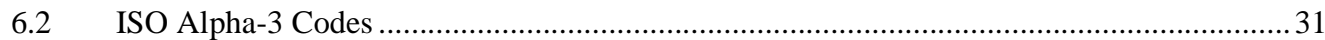




\section{Introduction}

This document explains our strategy for formatting standardized fertility, union, and home-leaving histories, as well as background variables. The document includes general specifications for the standardization process, but we highly recommend that researchers consult COUNTRY-SPECIFIC DOCUMENTATION to see how each variable was coded for each country. This documentation will be available to the user after he or she has received permission to use the data. Each survey has idiosyncrasies, which may result in inconsistencies in codes and missing variables. Although we have done the best to ensure comparability, researchers may decide they would like to recode some variables based on original data. We hold no responsibility for errors that may have arisen during the coding procedures.

An overview of the variables is given in the Appendix of this document.

\section{General Considerations}

\subsection{Two versions of the data are available}

One version of the data includes separate files for each country. The other version is combined into one pooled file.

Each database contains a variable ID and a three-digit country code (the first two numbers refer to the country, the third refers to a particular survey from that country see Appendix 1). Another country-specific ID is included so that the harmonized database can be merged with GGS databases, if available. The Original ID`s for Bulgaria and Russia were anonymized because of data protection.

The combined datafile contains the variable RESPID (ID number assigned at merging) and the country specific ID numbers (ARID).

For Bulgaria, the country specific ID is a string variable. Since all other countries had numeric variables for the ID, we replaced the Bulgarian country specific ID with a newly generated numeric variable called "idinew". 


\subsection{General set up of data (single record data)}

The data are in observation-unit format, with one observation per line. The data file is made of three kinds of variables: 1) a harmonized identification number to identify all respondents, and a country-specific identification number taken from each standard data file; 2) covariates that can be used to create time-varying histories; 3) background variables. All variable names are in caps.

For some variables the country specific coding is retained (e.g. education, ethnicity). These variables include a 3-digit country prefix (see Appendix for ISO Alpha-3 codes) followed by the codes from the original dataset. The variables are entered as integer variables. Below is an example from the German GGS and how it is transferred into the harmonized data set.

\section{Coding in the original data set}

1 Haupt- / (Volks-)schulabschluss bzw. Polytechnische Ober

2 Mittlere Reife, Realschulabschluss bzw. Polytechnische O

3 Fachhochschulreife

4 Allgemeine oder fachgebundene Hochschulreife (Abitur)

5 Anderer Schulabschluss

98 Weiß nicht

99 Keine Angabe

Germany code $=276$,

German GGS=1

Number of digits for country-specific codes $=2$

Total digits: 6

\section{Coding in the final data set}

276101 Haupt- / (Volks-)schulabschluss bzw. Polytechnische Ober

276102 Mittlere Reife, Realschulabschluss bzw. Polytechnische O

276103 Fachhochschulreife

276104 Allgemeine oder fachgebundene Hochschulreife (Abitur)

276105 Anderer Schulabschluss

2763198 Weiß nicht

2763199 Keine Angabe 


\section{How to delete the country code}

If necessary, the 3-digit country prefix can be removed with one of these Stata commands:

1) Transfer integer variable into string variable in order to include leading 0s.

gen newvar = string $($ oldvar, $\% 06.0 f ")$

2) Turn the variable back into a numeric variable and then the country code can be subtracted from the front. So if the string variable is "teststring", you could type

encode teststring, gen(testreal)

Subtract off the first digits mathematically.

Alternatively this can also be done in following procedure: Cut off the country code and encode the variable values.

tempvar newvar

gen 'newvar'=substr(testreal,4,.)

//This pulls off three columns of testreal starting at column 4

encode 'newvar', gen (testreal)

\subsection{Data set up for histories}

The dataset includes fertility, union and (first time) leaving home histories. There are two types of variables for the histories: 1) variables that indicate whether the person has experienced a certain event; 2) the dates of the occurrence of the event. All dates that correspond to the histories will be in the format month: $\mathrm{xx}$ (e.g. 12); year: $\mathrm{xxxx}$ (e.g. 1974).

\subsection{Coding of missing values}

Missing values are coded:
a: unknown
.b: does not apply
.c: unavailable in survey 


\subsection{Strategy for imputing missing dates}

Each dataset will include two types of variables: 1) original data 2) and original data that includes recoded or imputed data. In order to identify the imputed variables, a capital "I" is placed in front of the variable name.

Missing information for months is imputed with a uniformly distributed random variable. If information on the season is available, we use the following imputation scheme:

Winter months at the beginning of the year 21

Spring 22

Summer 23

Autumn 24

End of winter at end of year 25

Missing (.a)
Random variable between 1 and 2

Random variable between 3 and 5

Random variable between 6 and 8

Random variable between 9 and 11

12

Random variable between 1 and 12

In addition, the following strategies are followed: For the birth histories, the month of imputed birth should not fall within 9 months of the previous birth. In the union and marriage histories, the randomly imputed start of one union (marriage) should not occur before the end of the prior union (marriage) and the randomly imputed end of one union (marriage) should not occur before the subsequent one.

\section{Histories}

\subsection{Leaving home}

Only leaving home for the first time is included.

\subsection{Fertility histories}

Only biological children of the respondent are included in the fertility histories. Children are ordered chronologically according to their biological order. Another variable indicates if the respondent has any step, foster or adopted children. We cleaned illogical birth dates, for example if the birth dates of children occur before respondents' birth dates or before respondents turn 12 . 


\subsection{Union histories}

Each partnership is considered one union. Marriage dates are recorded as characteristics of the union. Couples that only (directly) marry have repeated information for union and marriage dates. Couples that are in unions without marrying can be considered to be cohabiting. Some marriages may also occur earlier than coresidence (for example, if a couple marries and then the husband serves in the army). For unions with a marriage date but no union date, we do not impute the beginning of a union based on marriage date.

In some countries (e.g. France), information was collected on civil unions as well as marriages. In these countries, MARR_\$ refers to the type of marriage.

A union can end through the death of partner or separation (variable SEP_\$). In case of separation, SEP_\$ is coded as 1, in case of death SEP_\$ is coded 2. The variable SEP_Y\$ refers to the year that the union ended. If the couple separated, the year of the end of the union is entered here. If the union ended by death of the partner, the death date is included in SEP_Y\$.

For marriages, the variable DIV_\$ indicates whether the marriage ended. If the dates for divorce and union dissolution are the same, both dates are provided. If only one question was asked about divorce or dissolution in the survey, then those dates are filled out, and the other question is marked with -3 .

Respondents who lose their partners through death are included in the separation variable, but not in the divorce variable. The divorce indicator is then marked with a 4 for widows.

We cleaned the data for unions only if divorces occurred before marriages (for the same union). We changed the divorce date to match the separation date, if available. We also corrected dates in which marriages or unions occurred before the birth of the respondent or before the respondent turned age 12 (since it is illegal to get married before that age in most countries).

\subsection{Partners' characteristics}

The partner characteristics refer to the respective union. For a list of union characteristics, see Appendix. 


\section{Background variables}

\subsection{Level of education}

There are three types of variables for the highest education level ever achieved:

First, there is "EDU_COU" which is the country specific coding of the level of education. The variable has 6 digits; the first three refer to the country, and the others are all country-specific codes. The variable labels are in the Appendix.

The second education variable is the ISCED classification from 1997. This variable is called "ISCED_7". Each researcher (or the UN research team) used the official ISCED classification for their country to generate this variable.

The third variable is "EDU_3", which collapses the 7 categories of the ISCED_7 variable into "high," "medium," and "low." Researchers may want to adjust these categories using other specifications of the ISCED categories or original data (see, for example, the BHPS data).

INSCHOOL refers to school enrollment at the time of the survey.

EDU_Y refers to the year the highest level of education achieved, according to the original data.

EDU_M refers to the month the highest level of education was achieved, according to the original data.

\subsubsection{Imputation of missing date of highest level of education}

A variable for the year (IEDU_Y) and the month (IEDU_M) of completion of education is provided. Missing information on these variables was imputed, based on information found in the survey for other respondents with similar levels of education. In order to impute the year of completion of education, a modal age by level of education is generated. This modal age is used to impute the missing information on the year of completion of education (by adding the modal age and the year of birth).

The month of graduation is imputed based on the mode of the month of all respondents who provided information. In many countries, the imputed month will be 6 (June). 
Some countries imputed the date of highest level of education achieved from an external source, for further information see the Country-specific Documentation.

\subsection{Time constant socio-demographic variables}

\subsubsection{Ethnicity, nationality etc.}

NATIVE indicates whether a respondent was born in country of interview.

ETHNOS refers to the original country-specific codes for ethnicity and nationality. The $1^{\text {st }} 3$ digits are the country code, and the $2^{\text {nd }}$ two refer to country-specific codes. BIRTH_COU is the respondent's birth country (see Appendix for standard list of countries).

If available, year (MIG_Y) and month (MIG_M) of migration to country of interview is included.

\subsubsection{Parental background}

Number of siblings is included as number of sisters, number of brothers, and total number of siblings. Number of brothers and sisters that died is also included. Most surveys do not specify whether siblings were step-siblings or adopted. Although some (e.g. Norway) only refer to biological siblings.

Mother and Father's occupation at age 15 is included as two types of variables. The first is a variable that includes country-code prefixes: WORK_MO \& WORK_FA. These variables refer to the original codes, but use 2 digit ISCO codes where available.

In addition, we included a 3-digit comparative variable: ISCO3_MO \& ISCO3_FA. This variable is based on ISCO-codes, but with only three categories:

Group 1 (High non manual): 1- Managers, 2- Professionals, 3- technicians and associate professionals

Group 2 (Non manual): 4- Clerical support workers, 5-service and sales workers, 0 - Armed forces

Group 3 (Manual): 6 - Skilled agricultural, forestry, fishery workers, 7 - Craft and related workers, 8Plants and machine operators and assemblers, 9 - Elementary occupations 
Furthermore, mother and father's education is included. Both variables are included in terms of ISCED-coding (ISCED_MO, ISCED_FA) as well as in terms of the regrouping into three educational categories (EDU3_MO, EDU3_FA).

NATIVE_MO and NATIVE_FA are indicator variables for whether the mother and father were born in the country of interview. BIRTHCO_MO and BIRTHCO_FA denote the country of origin of the parents (country coding).

There are two variables that capture whether the respondent has experienced parental divorce. PARDIVEV indicates whether the parents had ever divorced. PARDIV_15 indicates whether the respondent's parents divorced or separated before age 15:

1: Yes

2: No, stayed together

3: Never lived together

4: No, Parental death

5: No - no other info available in survey

Some countries include specific reasons for why parents never divorced - these reasons were recoded to fit categories 2-4. Countries with only yes/no answers filled out answer number 5 (No - no other info available in survey). Responses can then be collapsed as necessary depending on the countries used in a particular analysis.

\subsubsection{Characteristics of place of residence}

REGION denotes the country region at time of residence. This variable is country specific (e.g. Germany: East \& West; Italy: North $\&$ South). The $1^{\text {st }} 3$ digits refer to the country prefix, and the $2^{\text {nd }}$ two refer to country-specific codes.

Two variables refer to location size at the time of interview. One is country-specific and includes the 3-digit country prefix (SIZE). The other was constructed by MPIDR after examining the compatibility of all datasets (ISIZE). The variable ISIZE has been coded as follows:

1 Urban

2 Rural.

3 Other 
Another variable refers to location size at age 15 (SIZE15). The same coding procedures apply as above.

\subsubsection{Other background variables}

Two variables refer to religion at the time of interview. One is country-specific and includes 3-digit country codes (RELIGION). Another was constructed after examining the compatibility of all datasets (IRELIGION). For the standardized variable IRELIGION, the labels are:

1 Christian

2 Muslim

3 Other religion

4 No religion

There is also a variable for the total number of adopted children (ADOPT) and foster children (FOSTER). Also the total number of step-children is included (STEP).

\subsection{Weights}

Three variables for weights are included if available: Household weights (HHWGT), individual weights (PERSWGT), and kish weights (KISHWGT). 


\section{Country Specific Considerations/Coding}

\subsection{Overview}

\begin{tabular}{|c|c|c|c|c|c|}
\hline COUNTRY & $\begin{array}{l}\text { INTERVIEW } \\
\text { dates }\end{array}$ & Data & $\begin{array}{l}\text { Country } \\
\text { code }\end{array}$ & Respondents & Age range \\
\hline Total & & & & 224007 & \\
\hline Austria & $9 / 2008-3 / 2009$ & GGS & 401 & 5000 & $18-45$ \\
\hline Belgium & $2 / 2008-5 / 2010$ & GGS & 561 & 7163 & $18-82$ \\
\hline Bulgaria & $10 / 2004-12 / 2004$ & GGS & 1001 & 12858 & $17-85$ \\
\hline Czech Republic & $2 / 2004-4 / 2006$ & GGS & 2031 & 10006 & $17-80$ \\
\hline Estonia & $8 / 2004-12 / 2005$ & GGS & 2331 & 7855 & $21-81$ \\
\hline France & 2005 & GGS & 2501 & 10079 & $17-79$ \\
\hline Georgia & $3 / 2006-7 / 2006$ & GGS & 2681 & 10000 & $20-80$ \\
\hline Germany & $2005-06$ & GGS & 2761 & 10017 & $16-85$ \\
\hline Hungary & $10 / 2004-5 / 2005$ & GGS & 3481 & 9570 & $20-79$ \\
\hline Italy & $1 / 2003-12 / 2003$ & GGS & 3801 & 9570 & $18-64$ \\
\hline Lithuania & $4 / 2006-12 / 2006$ & GGS & 4401 & 10036 & $17-80$ \\
\hline Netherlands & $2 / 2003-4 / 2003$ & FFS & 5281 & 8145 & $18-63$ \\
\hline Norway & $1 / 2007-10 / 2008$ & GGS & 5781 & 14881 & $18-81$ \\
\hline Poland & $10 / 2006-12 / 2006$ & EFES & 6161 & 3005 & $24-40$ \\
\hline Poland & $01 / 2010-12 / 2011$ & GGS & 6162 & 19987 & $17-84$ \\
\hline Romania & $11 / 2005-12 / 2005$ & GGS & 6421 & 11986 & $18-80$ \\
\hline Russia & $6 / 2004-8 / 2004$ & GGS & 6431 & 11261 & $17-81$ \\
\hline Spain & $4 / 2006-5 / 2006$ & SFS & 7241 & 9737 & $14-97$ \\
\hline UK & 9/2005-4/2006 & BHPS & 8261 & 14539 & $16-80,5$ \\
\hline USA & $1 / 1995-10 / 1995$ & NSFG & 8401 & 10847 & $14-45$ \\
\hline USA & $6 / 2006-12 / 2008$ & NSFG & 8402 & 13495 & $14-45$ \\
\hline
\end{tabular}




\subsection{GGS-Countries}

\section{Austria}

For Austria, the original data comes from the first wave of the Generations and Gender Survey, conducted in 2008 and 2009. The total sample includes 3001 women and 1999 men aged 18-46 at the time of interview. The data for the Harmonized Histories were prepared by Caroline Berghammer (Vienna Institute of Demography).

Acknowledgments: The Austrian GGS was conducted by Statistics Austria with the financial support of the Federal Ministry of Economy, Family and Youth, the Federal Ministry of Science and Research and the Federal Ministry of Labour, Social Affairs and Consumer Protection. The international GGS templates (survey instruments, sample design) were adapted to the Austrian context by the Vienna Institute of Demography and the Austrian Institute for Family Studies. The Austrian Institute for Family Studies has also coordinated the Generations and Gender Programme for Austria.

\section{Belgium}

For Belgium, the original data comes from the first wave of the Generations and Gender Survey, conducted in 2008-2010. We used the standardized version provided by the UN (release GGS-Wave1_Belgium_V3.0.dta). The total sample includes 3728 women and 3435 men aged 18-82 at the time of interview. The data for the Harmonized Histories were prepared by Karolin Kubisch (Max Planck Institute for Demographic Research).

Acknowledgements: These data were obtained from the GGP archive (for more information see: http://www.ggp-i.org/). Please see United Nations (2005) for details on the survey instrument. 


\section{Bulgaria}

For Bulgaria, the original data comes from the first wave of the Generations and Gender Survey, conducted in 2004. The total sample includes 7007 women and 5851 men aged 18-85 at the time of interview. The Bulgarian data file contains the variable ARID in a string format. For Bulgaria a new numeric ID number "idinew" had to be created. The data for the Harmonized Histories were prepared by Karolin Kubisch (Max Planck Institute for Demographic Research).

Acknowledgments: The Bulgarian GGS was conducted with the financial support of the Max-Planck-Gesellschaft, Germany. The survey instruments and design were developed by the Institute of Sociology at the Bulgarian Academy of Sciences, the Center for Population Studies at the Bulgarian Academy of Sciences, and the National Statistical Institute (Sofia) in collaboration with the Max Planck Institute for Demographic Research (Rostock, Germany).

\section{Czech Republic}

For the Czech Republic the original data comes from the first wave of the Generations and Gender Survey, conducted in 2004-2006. We used the standardized version provided by the UN (release GGS_Wave1_CzechRepublic_V4.2.dta). The total sample includes 5209 women and 4797 men aged 17-80 at the time of interview. The data for the Harmonized Histories were prepared by Karolin Kubisch (Max Planck Institute for Demographic Research).

Acknowledgements: These data were obtained from the GGP archive (for more information see: http://www.ggp-i.org/). Please see United Nations (2005) for details on the survey instrument. 


\section{Estonia}

For Estonia, the original data comes from the first wave of the Generations and Gender Survey, conducted in 2004-2005. We used the standardized version provided by the UN (release GGS-Wave1_Estonia_V3.0.dta). The total sample includes 5034 women and 2821 men aged 21-81 at the time of interview. The data for the Harmonized Histories were prepared by Karolin Kubisch (Max Planck Institute for Demographic Research).

Acknowledgements: These data were obtained from the GGP archive (for more information see: http://www.ggp-i.org/). Please see United Nations (2005) for details on the survey instrument.

\section{France}

For France, data comes from the first wave of the Generations and Gender Survey, conducted in 2005. We used the standardized version provided by the UN (release GGS-wave1_France_V1.7.dta). The total sample includes 5708 women and 4371 men aged 18-80 at the time of interview.

The data for the variable EDU_COU are based on the ISCED97 coded variables from the UN harmonized version, and include categories not consistent with our ISCED_7 codes. Thus, we created two new ISCED_7 codes (codes 7 and 8). Because the month of highest level of education achieved is not included in the survey, we imputed June for all missing cases. The data for the Harmonized Histories were prepared by Karolin Kubisch (Max Planck Institute for Demographic Research).

Acknowledgements: These data were obtained from the GGP archive (for more information see: http://www.ggp-i.org/). Please see United Nations (2005) for details on the survey instrument. 


\section{Georgia}

For Georgia the original data comes from the first wave of the Generations and Gender Survey, conducted in 2006. We used the standardized version provided by the UN (release GGS_Wave1_Georgia_V4.1.dta). The total sample includes 5595 women and 4405 men aged 20-80 at the time of interview. The data for the Harmonized Histories were prepared by Karolin Kubisch (Max Planck Institute for Demographic Research).

Acknowledgements: These data were obtained from the GGP archive (for more information see: http://www.ggp-i.org/). Please see United Nations (2005) for details on the survey instrument.

\section{Germany (East and West)}

For Germany, we use data from the first wave of the Generations and Gender Survey, provided by the Bundesinstitut für Bevölkerungsforschung $(\mathrm{BiB})$. The survey was conducted in 2005 and includes respondents aged 17-85 at the time of interview. The total number of respondents is 10017. For more information on the German data set, see Ruckdeschel et al. (2006).

No information on the month of interview is available in the German GGS. As noted by Ruckdeschel et al. (2006), the German interviews were conducted between February and May 2005. Also, no information on the death dates of the partners is available in the German data set.

Although we include the German GGS in the Harmonized Histories, we URGE CAUTION in using the union and fertility histories. Comparisons with other surveys and official estimates show that partnerships in the German GGS are underreported, in particular for older cohorts (Kreyenfeld et al 2010). Births also appear to be overreported for the older and underreported for the younger cohorts. The data for the Harmonized Histories were prepared by Karolin Kubisch (Max Planck Institute for Demographic Research). Contact person: Michaela Kreyenfeld

Acknowledgments: The German data were provided by the Bundesinstitut für Bevölkerungsforschung (BIB) (see also Ruckdeschel et al. 2006). 


\section{Hungary}

The Hungarian data comes from the first wave of the Generations and Gender Survey (originally called "Turning points of the life-course"). To create the Hungarian Harmonized History, we use the standardized version provided by the UN (release GGS-wave1_Hungary_V1.7.dta). The Hungarian GGS was conducted in 2004-2005. The sample includes 13540 respondents (7517 males and 6023 females) aged 21-79 at the time of the interview.

Leaving home questions are not included in the survey.

The variable EDU_COU is based on the ISCED97 codes from the UN survey and includes one category not consistent with our ISCED_7 codes. Thus, we created a new ISCED_7 code (code 9). The month of highest level of education achieved is not included in the survey, and we imputed June for all missing cases. Many background variables are not included in the Hungarian GGS. The data for the Harmonized Histories were prepared by Karolin Kubisch (Max Planck Institute for Demographic Research).

Acknowledgements: These data were obtained from the GGP archive (for more information see: http://www.ggp-i.org/). Please see United Nations (2005) for details on the survey instrument.

\section{Italy}

The Italian data come from the first wave of the Generations and Gender Survey, conducted in December 2003. To create the Italian Harmonized Histories, we used the standardized version release GGS-wave1_Italy_V3.0.dta). The sample consists of 9670 respondents aged 18-64 at the time of interview. The variable BORN_Y is not included. The data for the Harmonized Histories were prepared by Karolin Kubisch (Max Planck Institute for Demographic Research). 
Acknowledgements: These data were obtained from the GGP archive (for more information see: http://www.ggp-i.org/). Please see United Nations (2005) for details on the survey instrument.

\section{Norway}

For Norway, the original data comes from the first wave of the Generations and Gender Survey, conducted in 2007-2008. To create the Norwegian Harmonized History, we use the standardized version provided by the UN (release GGSwave1_Norway_V3.0.dta). The total sample includes 7541 women and 7340 men aged 19-81 at the time of interview. The data for the Harmonized Histories were prepared by Karolin Kubisch (Max Planck Institute for Demographic Research).

Acknowledgements: These data were obtained from the GGP archive (for more information see: http://www.ggp-i.org/). Please see United Nations (2005) for details on the survey instrument. The Norwegian GGS was conducted by the Division for Social and Demographic Research, Statistics Norway and NOVA (Norwegian Social Research), with additional funding from the Research Council of Norway

\section{Poland}

For Poland the original data comes from the first wave of the Generations and Gender Survey, conducted in 2010-2011. We used the standardized version provided by the UN (release GGS_Wave1_Poland_V4.2.dta). The total sample includes 11578 women and 8409 men aged 17-84 at the time of interview. The data for the Harmonized Histories were prepared by Karolin Kubisch (Max Planck Institute for Demographic Research).

Acknowledgements: These data were obtained from the GGP archive (for more information see: http://www.ggp-i.org/). Please see United Nations (2005) for details on the survey instrument. 


\section{Romania}

For Romania, the original data is from the first wave of the Generations and Gender Survey, carried out in November/December 2005. The sample consists of 11986 respondents (5977 men and 6009 women) aged 18-80 at the time of interview.

In the Romanian datafile the following variables are not included: number of children ever lived with respondent (NUMCLIV) and the size of place of residence at age 15 (SIZE_15). The data for the Harmonized Histories were prepared by Karolin Kubisch (Max Planck Institute for Demographic Research).

Acknowledgments: The Romanian GGS was conducted with the financial support of UNFPA, the United Nations Population Fund, Romania and the Max-PlanckGesellschaft, Germany. The survey instruments and design were developed by the National Statistical Institute (Bucharest, Romania) in collaboration with the Max Planck Institute for Demographic Research (Rostock, Germany).

\section{Russia}

The Russian harmonized history is based on Wave 1 of the Generations and Gender Survey. Wave 1 of this nationally representative survey conducted interviews with 4223 men and 7038 women aged 17-81 in June - August of 2004. The overall response rate was $44 \%$, but comparisons show that the GGS is generally comparable with the Russian census in terms of major population characteristics (Houle and Shkolnikov 2005). However, the GGS has a very low response-rate (15\%) in the largest urban areas of Russia - Moscow and St. Petersburg. Thus, the survey may not be representative of these major urban areas. The data for the Harmonized Histories were prepared by Karolin Kubisch (Max Planck Institute for Demographic Research).

Acknowledgments: The Russian GGS was conducted by the Independent Institute of Social Policy (Moscow) with the financial support of the Pension Fund of the Russian Federation and the Max-Planck-Gesellschaft, Germany. The design and standard survey instruments of the GGS were adjusted to the Russian context by the Independent Institute of Social Policy (Moscow) and the Demoscope Independent 
Research Center (Moscow) in collaboration with the Max Planck Institute for Demographic Research (Rostock, Germany).

\subsection{Non-GGS Countries}

\section{Great Britain BHPS}

The British Household Panel Survey (BHPS) is an annual survey. It originally consisted of a nationally representative sample of about 5500 households recruited in 1991. Individuals are added to the panel when they join BHPS households, and individuals who leave BHPS households and form their own households are followed (and all adult members of these new households are interviewed). Extension samples of 1500 households in each of Scotland and Wales were added to the main BHPS sample in 1999 to enable independent analysis of each country. In 2001 a sample of 2000 households was added in Northern Ireland. Because the extension samples make the BHPS sample unrepresentative, it is important that descriptive statistics are calculated using sample weights.

Information on birth and partnership histories comes from the retrospective information provided in the first (extension samples) or second (original sample) waves of interview, from information in the panel, or a combination of the two.

Although information on fertility and partnership status are collected prospectively, retrospective birth histories and partnership histories were collected from all sample members aged 16 and older. Information extending back to the 1970s depends on the quality of retrospective information and may differ between the original (for whom retrospective information was collected in 1992) and the extension samples (who provided retrospective histories when they entered the panel) if we assume that the quality of retrospective recall declines over time. Children are interviewed as they reach the age of 16 so information on the fertility and partnerships of those sample members who turned 16 after the retrospective information was collected comes exclusively from the panel.

The sample consists of 14539 respondents, 6683 men and 7856 women - aged 16-80 at the time of interview - who were interviewed in the 2005-06 wave of data collection. 
Questions concerning the respondents' age at leaving home are not available in the survey. Information on children's deaths and dates of leaving home are extremely incomplete and not included in the database .

Some respondents did not provide information on the start date of a (usually the first) union. However, we often observe these respondents in a union at the time of the survey. Using this information, four country specific left truncated variables were created (for the year and month of the start dates of UNION and MARRIAGE). Researchers should take care when using these variables because left truncated variables may overstate the percentage of single births particularly those that occurred prior to 1991, the first year of the survey.

The year and month highest level of education achieved are not available and had to be imputed based on information about British education system. Researchers should review the ISCED classification scheme because individuals with $\mathrm{O}$ level qualifications or equivalent (obtained at around age 15) and A-level qualifications (obtained at around age 17 or 18) are placed in the same category. Moreover, the BHPS variable that contains information on highest qualification (both academic and vocational) contains a large category "other higher qualification". There is very little information available about the exact qualifications that comprise this category. When these respondents are coded as highly educated (as we have done with ISCED3 ), the percentage of people with a high education is very high. We have also included a variable which includes highest academic qualifications. Many of the respondents in the "other higher qualification" category have O-level or A-level academic qualifications. Researchers may want to use this variable to construct their educational qualifications variable or make decisions on how to code the "other higher qualification group".

The data for the Harmonized Histories were prepared by Wendy Sigle-Rushton (The London School of Economics and Political Science).

Acknowledgments: The BHPS study is funded by the Economic and Social Research Council (ESRC). The data was originally collected by the ESRC Research Centre on Micro-Social Change at the University of Essex. Over time, additional funding for the British Household Panel Survey (BHPS) has been provided by the Health Education Authority (HEA), Office for National Statistics (ONS) and Eurostat. The HEA helped 
to carry out the survey of 11-15 year old members of the BHPS sample included from Wave 4 onwards. The Northern Ireland sample, included from Wave 11, is jointly funded by the Economic and Social Research Council (ESRC) and various Northern Ireland government departments. Chiara Daniela Pronzato cleaned the fertility and partnership histories (Pronzato 2007).

\section{Netherlands FFS}

The Dutch data comes from the Fertility and Family Survey which was carried out in 2003. The sample consists of 8145 respondents, 3916 men and 4229 women aged 1863 at the time of interview. In the partnership histories the month of birth of partner (MONBIRP_\$) and the questions about the children of partner (NUMCLIV; NUMCHP) are not available. In the fertility histories the questions about the death of children are not included in the survey. The year and month of highest level of education achieved are also not available and had to be imputed by Renske Keizer. Many background variables (NATIVE, ETHNOS, BIRTH_COU, MIG_Y, MIG_M IMIG_M, SIS_NO, BRO_NO, SIS_DIED, BRO_DIED, WORK_MO,WORK_FA, ISCO3_MO, ISCO3_FA, NATIVE_MO, NATIVE_FA, BIRTHCO_MO, BIRTHCO_FA, REGION, SIZE,) are also not available. A specialty of the Dutch data file is the existence of a country specific variable NONBIOKI (number of nonbiological children) which had to be created. In the Dutch data file the variables ADOPT, FOSTER and STEP are not included. The data for the Harmonized Histories were prepared by Renske Keizer (Erasmus Universiteit Rotterdam).

Acknowledgments: Data about the Netherlands are derived from the The Family and Fertility Survey 2003 (Onderzoek Gezinsvorming). The FFS contains detailed information about relationships and family (formation). Data were collected by Statistics Netherlands (www.cbs.nl).

\section{Poland}

The Polish data come from the Employment, Family and Education Survey which was carried out in 2006. The sample consists of 3005 female respondents, aged 25-40 at 
the time of interview. The data for the Harmonized Histories were prepared by Anna Baranowska (Warsaw School of Economics).

Acknowledgments: The EFES contains detailed information about relationships and family formation. The data were collected by TNS OBOP. The Employment, Family and Education Survey was carried out within the project "Structural and cultural conditions of female labour force participation in Poland" financed by the Ministry of Science and Higher Education.

\section{Spain}

The data comes from Survey of Fertility and Values. The sample consists of 9737 female respondents, who were 15-98 at the time of interview. The data for the Harmonized Histories were prepared by Alicia Adsera (Princeton University)

Acknowledgments: "The Survey of Fertility and Values was collected by the Centro de Investigaciones Sociológicas, but it is still undergoing processing. Therefore, the CIS holds no responsibility for any inaccuracies found in the data."

\section{USA}

The U.S. data comes from the 1995 and 2006-08 waves of the National Survey of Family Growth. The 1995 sample consists of 10847 female respondents, who were 15-44 at the time of interview. The 2007 sample, collected between 2006 and 2008, consists of 13495 men and women who were 15-44 at the time of the interview.

The data for the Harmonized Histories were prepared by Katherine Michelmore (Cornell University). Contact person: Kelly Musick

Acknowledgments: The National Survey of Family Growth was conducted by the Division of Vital Statistics at the U.S. Centers for Disease Control. 


\section{References}

Houle, Rene and Vladimir Shkolnikov. 2005. "Low response rates in the cities of Moscow and Sankt-Peterburg and GGS-Census comparisons of basic distributions." Max Planck Institute for Demographic Research.

Kreyenfeld, Michaela/ Hornung, Anne/ Kubisch, Karolin/ Jaschinski, Ina (2010): Fertility and union histories from German GGS data: Some critical reflections. MPIDR-Working Paper 2010-23.

Pronzato, C. (2007): British Household Panel Survey Consolidated Marital, Cohabitation and Fertility Histories, 1991-2006, ISER, University of Essex, distributor: UKDA.

Ruckdeschel, K./ Ette, A. Hullen, G. / Leven, I. (2006): Generations and Gender Survey. Dokumetation der ersten Welle der Hauptbefragung Deutschland. Wiesbaden: Bundesinstitut für Bevölkerungsforschung.

United Nations. 2005. Generations and Gender Programme: Survey Instruments. New York and Geneva: UN, 2005. 


\section{Appendix}

\subsection{Variables}

\begin{tabular}{|c|c|c|}
\hline Variable & Description & Coding of variables \\
\hline RESPID & $\begin{array}{l}\text { ID number assigned by } \\
\text { MPIDR }\end{array}$ & \\
\hline ARID & $\begin{array}{l}\text { ID number from raw data-this } \\
\text { number can be used to connect } \\
\text { histories with original data, if } \\
\text { appropriate }\end{array}$ & Original ID number \\
\hline COUNTRY & Country and survey & \\
\hline MONTH_S & Month of survey & a: unknown \\
\hline IMONTH_S & $\begin{array}{l}\text { Month of survey, including } \\
\text { imputed dates }\end{array}$ & $\begin{array}{l}\text { See each country description } \\
\text { for details about how survey } \\
\text { month was imputed }\end{array}$ \\
\hline YEAR_S & Year of survey & \\
\hline SEX & Sex of the respondent & $\begin{array}{l}\text { 1: male } \\
2: \text { female }\end{array}$ \\
\hline BORN_Y & Year of birth of respondent & a: unknown \\
\hline BORN_M & Month of birth of respondent & a: unknown \\
\hline IBORN_M & $\begin{array}{l}\text { Month of birth of respondent, } \\
\text { includes imputed months }\end{array}$ & \\
\hline \multicolumn{3}{|c|}{ Leaving home } \\
\hline LEAVE_1 & Indicator of whether left home & $\begin{array}{l}\text { 0: did not leave home } \\
\text { 1: left home } \\
\text { a: unknown } \\
\text {.c: unavailable in survey }\end{array}$ \\
\hline LEAVE_Y1 & Year of first time leaving home & $\begin{array}{l}\text { a: unknown } \\
\text {.b: does not apply } \\
\text {.c: unavailable in survey }\end{array}$ \\
\hline LEAVE_M1 & $\begin{array}{l}\text { Month of first time leaving } \\
\text { home }\end{array}$ & $\begin{array}{l}\text { a: unknown } \\
\text {.b: does not apply } \\
\text {.c: unavailable in survey }\end{array}$ \\
\hline ILEAVE_M1 & $\begin{array}{l}\text { Month of first time leaving } \\
\text { home and imputed values }\end{array}$ & $\begin{array}{l}\text { b: does not apply } \\
\text {.c: unavailable in survey }\end{array}$ \\
\hline \multicolumn{3}{|c|}{ Unions ( $\$=$ order of union) } \\
\hline UNINUM & Total number of unions & a: unknown \\
\hline UNION_\$ & Indicator of union order & $\begin{array}{l}\text { a: unknown } \\
\text { 1: union of order } \$ \\
0: \text { no union of order } \$\end{array}$ \\
\hline UNION_Y\$ & Year of start of union & $\begin{array}{l}\text { a: unknown } \\
\text {.b: does not apply }\end{array}$ \\
\hline UNION_M\$ & Month of start of union & $\begin{array}{l}\text {-a: unknown } \\
\text {.b: does not apply }\end{array}$ \\
\hline IUNION_M\$ & $\begin{array}{l}\text { Month of start of union, } \\
\text { including imputed months }\end{array}$ & b: does not apply \\
\hline SEP_\$ & Dissolution of union & $\begin{array}{l}\text { 0: no separation } \\
\text { 1: separation } \\
\text { 2: death of partner } \\
\text { a: unknown } \\
\text {.b: does not apply } \\
\text {.c: unavailable in survey }\end{array}$ \\
\hline
\end{tabular}




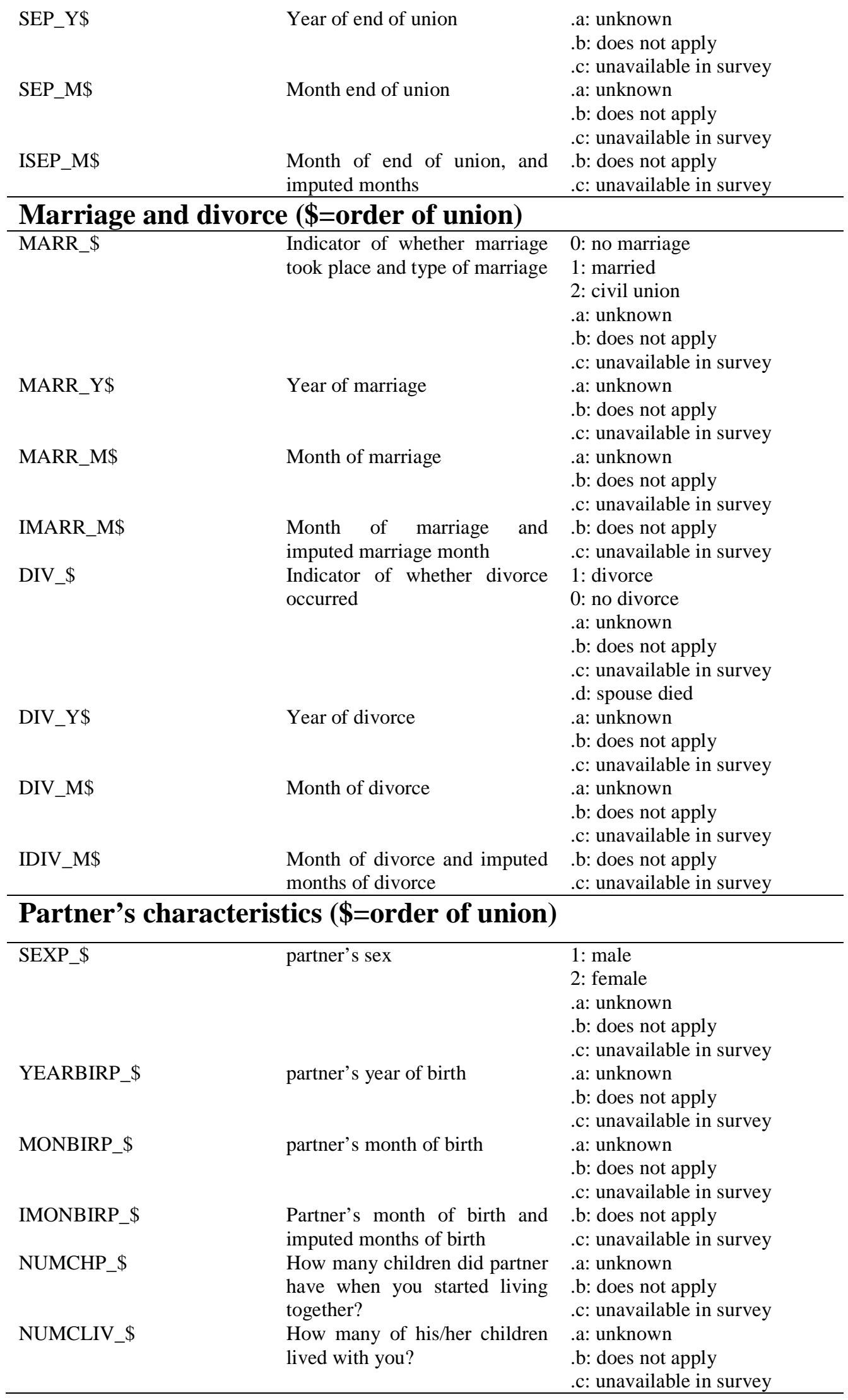




\begin{tabular}{|c|c|c|}
\hline \multicolumn{3}{|c|}{ Birth histories (biological kids) } \\
\hline KID_\$ & $\begin{array}{l}\text { Indicator of child order } \\
\text { (provides info if child was } \\
\text { born, even if birth date } \\
\text { unknown) }\end{array}$ & $\begin{array}{l}0: \text { no child of order } \$ \\
1: \text { child of order } \$ \\
\text { a: unknown } \\
\text {.c: unavailable in survey }\end{array}$ \\
\hline KID_Y\$ & Year of birth of child & $\begin{array}{l}\text { a: unknown } \\
\text {.b: does not apply } \\
\text {.c: unavailable in survey }\end{array}$ \\
\hline KID_M\$ & Month of birth of child & $\begin{array}{l}\text { a: unknown } \\
\text {.b: does not apply } \\
\text {.c: unavailable in survey }\end{array}$ \\
\hline IKID_M\$ & $\begin{array}{l}\text { Month of birth of child and } \\
\text { imputed months }\end{array}$ & $\begin{array}{l}\text {.b: does not apply } \\
\text {.c: unavailable in survey }\end{array}$ \\
\hline KID_S\$ & Sex of child & $\begin{array}{l}\text { a: unknown } \\
\text {.b: does not apply } \\
\text {.c: unavailable in survey }\end{array}$ \\
\hline KID_D\$ & Death of child & $\begin{array}{l}\text { a: unknown } \\
\text {.b: does not apply } \\
\text {.c: unavailable in survey }\end{array}$ \\
\hline KID_DY\$ & Year of death of child & $\begin{array}{l}\text { a: unknown } \\
\text {.b: does not apply } \\
\text {.c: unavailable in survey }\end{array}$ \\
\hline KID_DM\$ & Month of death of child & $\begin{array}{l}\text { a: unknown } \\
\text {.b: does not apply } \\
\text {.c: unavailable in survey }\end{array}$ \\
\hline IKID_DM\$ & $\begin{array}{l}\text { Month of death of child and } \\
\text { imputed months }\end{array}$ & $\begin{array}{l}\text {.b: does not apply } \\
\text {.c: unavailable in survey }\end{array}$ \\
\hline KID_L\$ & Child left home & $\begin{array}{l}\text { a: unknown } \\
\text {.b: does not apply } \\
\text {.c: unavailable in survey }\end{array}$ \\
\hline KID_LY\$ & Year child left home & $\begin{array}{l}\text { a: unknown } \\
\text {.b: does not apply } \\
\text {.c: unavailable in survey }\end{array}$ \\
\hline KID_LM\$ & Month child left home & $\begin{array}{l}\text { a: unknown } \\
\text {.b: does not apply } \\
\text {.c: unavailable in survey }\end{array}$ \\
\hline IKID_LM\$ & $\begin{array}{l}\text { Month child left home and } \\
\text { imputed months }\end{array}$ & $\begin{array}{l}\text {.b: does not apply } \\
\text {.c: unavailable in survey }\end{array}$ \\
\hline \multicolumn{3}{|c|}{ Education } \\
\hline INSCHOOL & $\begin{array}{l}\text { Currently studying at the time } \\
\text { of the interview }\end{array}$ & $\begin{array}{l}\text { 1: yes } \\
2 \text { : no } \\
\text {.a: unknown } \\
\text {.c: unavailable in survey }\end{array}$ \\
\hline EDU_COU & $\begin{array}{l}\text { Highest level of education } \\
\text { achieved; country specific }\end{array}$ & $\begin{array}{l}\text { Country-specific coding } \\
\text { a: unknown }\end{array}$ \\
\hline ISCED_7 & $\begin{array}{l}\text { Highest level of education } \\
\text { achieved according to ISCED } \\
1997\end{array}$ & $\begin{array}{l}\text {.a: unknown } \\
\text { 1: ISCED } 0+1 \\
\text { 2: ISCED } 2 \\
\text { 3: ISCED } 3 \\
\text { 4: ISCED } 4 \\
\text { 5: ISCED } 5 \\
\text { 6: ISCED } 6 \\
\text { 7: ISCED 0+1+2 (France) } \\
\text { 8:ISCED 5+6 (France) } \\
\text { 9:ISCED 3+4 (Hungary) }\end{array}$ \\
\hline EDU_3 & $\begin{array}{l}\text { Highest level of education, } \\
\text { ISCED collapsed into } 3 \\
\text { categories }\end{array}$ & $\begin{array}{l}\text { 1: high } \\
\text { 2: medium } \\
\text { 3: low }\end{array}$ \\
\hline
\end{tabular}




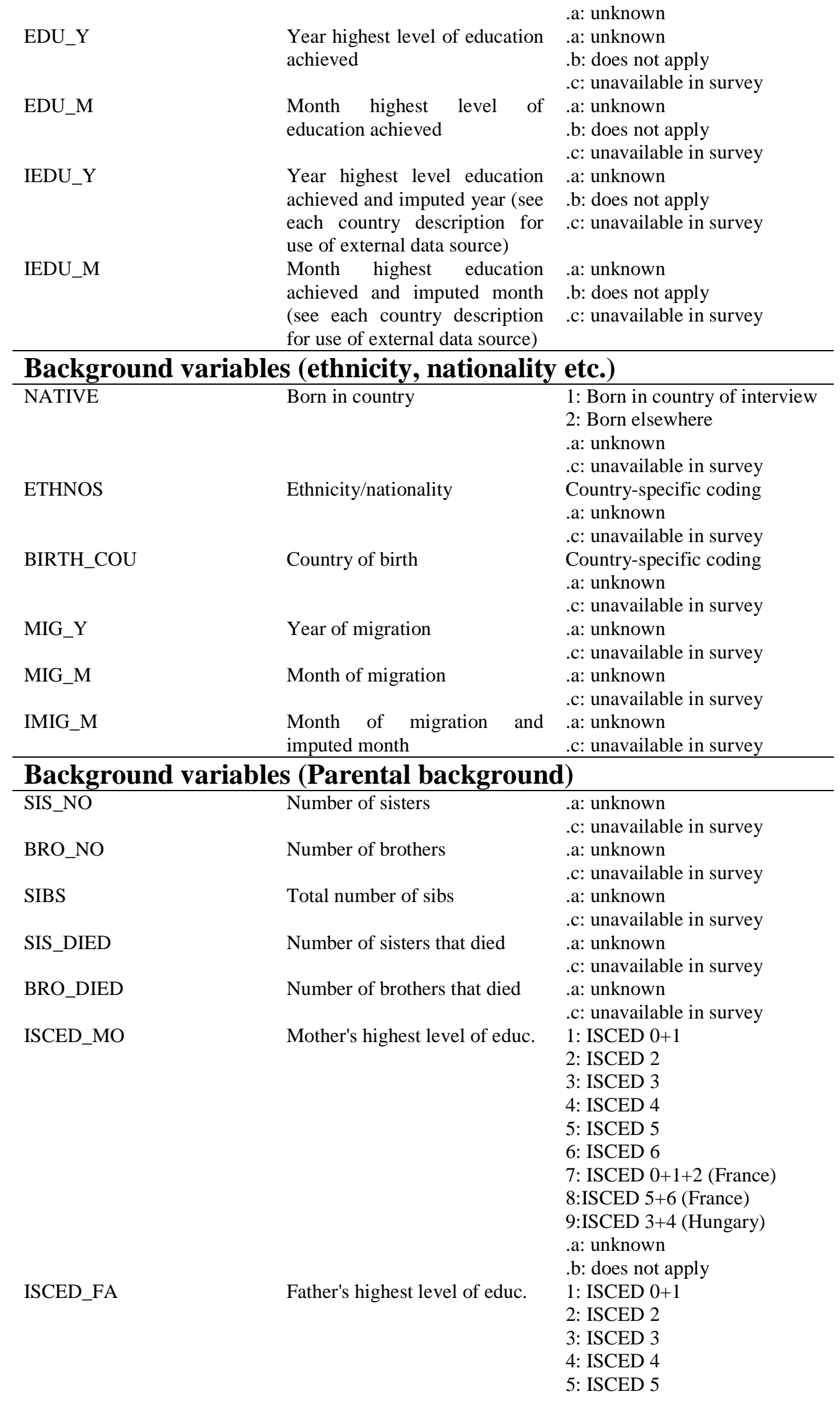


EDU3_MO

EDU3_FA

WORK_MO

WORK_FA

ISCO3_MO

ISCO3_FA

NATIVE_MO

NATIVE_FA

BIRTHCO_MO

BIRTHCO_FA

PARDIVEV

PARDIV_15
Highest level of education of mother, ISCED 1997 collapsed into 3 categories

Highest level of education of father, ISCED 1997 collapsed into 3 categories

Mother's occupation when respondent was 15 (Original country-codes; Two digit ISCO codes where possible)

Father's occupation when respondent was 15 (Original country-codes; Two digit ISCO codes where possible)

Mother's occupation when respondent was $15 \quad$ (3 categories)

Father's occupation when respondent was 15 categories)

Mother born in country

Father born in country

Mother's country of origin

Father's country of origin

Parents ever divorced/separated

Parents divorced/ separated
before age of 15/16
6: ISCED 6

7: ISCED 0+1+2 (France)

8:ISCED 5+6 (France)

9:ISCED 3+4 (Hungary)

.a: unknown

.b: does not apply

1: high

2: medium

3: low

a: unknown

1: high

2: medium

3: low

a: unknown

a: unknown

.b: does not apply

.c: unavailable in survey

a: unknown

.b: does not apply

.c: unavailable in survey

.a: unknown.

.b: does not apply

.c: unavailable in survey

.a: unknown

.b: does not apply

.c: unavailable in survey

1 : Born in country

2: Born elsewhere

a: unknown

.c: unavailable in survey

1 : Born in country

2: Born elsewhere

a: unknown

.c: unavailable in survey

Country-specific coding

a: unknown

.c: unavailable in survey

Country-specific coding

a: unknown

.c: unavailable in survey

1: Yes

2: No, stayed together

3: Never lived together

4: No, parental death

5: No - no other info available

in survey

a: unknown

.c: unavailable in survey

1: Yes

2: No, stayed together

3: Never lived together

4: No, parental death

5: No - no other info available

in survey

a: unknown

.c: unavailable in survey 


\begin{tabular}{|c|c|c|}
\hline \multicolumn{3}{|c|}{ Background variables (Region, size of location) } \\
\hline REGION & $\begin{array}{l}\text { Country region at time of } \\
\text { interview }\end{array}$ & $\begin{array}{l}\text { Country-specific coding } \\
\text {.a: unknown } \\
\text {.c: unavailable in survey }\end{array}$ \\
\hline SIZE & $\begin{array}{l}\text { Size of place of residence at } \\
\text { time of interview }\end{array}$ & $\begin{array}{l}\text { Country specific coding } \\
\text {.a: unknown } \\
\text {.c: unavailable in survey }\end{array}$ \\
\hline ISIZE & $\begin{array}{l}\text { Size of place of residence at } \\
\text { time of interview -standardized } \\
\text { code }\end{array}$ & $\begin{array}{l}1 \text { Urban } \\
2 \text { Rural } \\
3 \text { Other }\end{array}$ \\
\hline SIZE_15 & $\begin{array}{l}\text { Size of place of residence at } \\
\text { age } 15\end{array}$ & $\begin{array}{l}\text { Country specific coding } \\
\text {.a: unknown } \\
\text {.c: unavailable in survey }\end{array}$ \\
\hline ISIZE_15 & $\begin{array}{l}\text { Size of place of residence at } \\
\text { age } 15 \text { - standardized code }\end{array}$ & $\begin{array}{l}1 \text { Urban } \\
2 \text { Rural } \\
3 \text { Other }\end{array}$ \\
\hline \multicolumn{3}{|c|}{ Other background variables } \\
\hline RELIGION & $\begin{array}{l}\text { Religious affiliation at time of } \\
\text { interview }\end{array}$ & $\begin{array}{l}\text { Country specific coding } \\
\text {.a: unknown } \\
\text {.c: unavailable in survey }\end{array}$ \\
\hline IRELIGION & $\begin{array}{l}\text { Religious affiliation at time of } \\
\text { interview, recoded }\end{array}$ & $\begin{array}{l}1 \text { Christian } \\
2 \text { Muslim } \\
3 \text { Other } \\
4 \text { No religion }\end{array}$ \\
\hline ADOPT & $\begin{array}{l}\text { Number of adopted children of } \\
\text { respondent }\end{array}$ & $\begin{array}{l}\text {.a: unknown } \\
\text {.c: unavailable in survey }\end{array}$ \\
\hline FOSTER & $\begin{array}{l}\text { Number of foster children of } \\
\text { respondent }\end{array}$ & $\begin{array}{l}. \text { a: unknown } \\
\text {.c: unavailable in survey }\end{array}$ \\
\hline STEP & $\begin{array}{l}\text { Number of stepchildren of } \\
\text { respondent }\end{array}$ & $\begin{array}{l}\text {.a: unknown } \\
\text {.c: unavailable in survey }\end{array}$ \\
\hline \multicolumn{3}{|l|}{ Weights } \\
\hline HHWGT & Household weight & .c: unavailable in survey \\
\hline PERSWGT & Personal weight & .c: unavailable in survey \\
\hline KISHWGT & Kishweight & .c: unavailable in survey \\
\hline
\end{tabular}




\subsection{ISO Alpha-3 Codes}

\begin{tabular}{|c|c|c|c|c|c|}
\hline $\begin{array}{l}\text { Numerical } \\
\text { code }\end{array}$ & Country & $\begin{array}{l}\text { ALPHA_3 } \\
\text { code }\end{array}$ & $\begin{array}{l}\text { Numerical } \\
\text { code }\end{array}$ & Country & $\begin{array}{l}\text { ALPHA_3 } \\
\text { code }\end{array}$ \\
\hline & & & & Libyan Arab & \\
\hline 4 & Afghanistan & AFG & 434 & Jamahiriya & LBY \\
\hline 248 & Åland Islands & ALA & 438 & Liechtenstein & LIE \\
\hline 8 & Albania & ALB & 440 & Lithuania & LTU \\
\hline 12 & $\begin{array}{l}\text { Algeria } \\
\text { American }\end{array}$ & DZA & 442 & Luxembourg & LUX \\
\hline 16 & Samoa & ASM & 450 & Madagascar & MDG \\
\hline 20 & Andorra & AND & 454 & Malawi & MWI \\
\hline 24 & Angola & $\mathrm{AGO}$ & 458 & Malaysia & MYS \\
\hline 660 & $\begin{array}{l}\text { Anguilla } \\
\text { Antigua and }\end{array}$ & AIA & 462 & Maldives & MDV \\
\hline 28 & Barbuda & ATG & 466 & Mali & MLI \\
\hline 32 & Argentina & ARG & 470 & $\begin{array}{l}\text { Malta } \\
\text { Marshall }\end{array}$ & MLT \\
\hline 51 & Armenia & ARM & 584 & Islands & MHL \\
\hline 533 & Aruba & $\mathrm{ABW}$ & 474 & Martinique & MTQ \\
\hline 36 & Australia & AUS & 478 & Mauritania & MRT \\
\hline 40 & Austria & AUT & 480 & Mauritius & MUS \\
\hline 31 & Azerbaijan & AZE & 175 & Mayotte & MYT \\
\hline 44 & Bahamas & BHS & 484 & $\begin{array}{l}\text { Mexico } \\
\text { Micronesia, } \\
\text { Federated }\end{array}$ & MEX \\
\hline 48 & Bahrain & BHR & 583 & States of & FSM \\
\hline 50 & Bangladesh & BGD & 492 & Monaco & $\mathrm{MCO}$ \\
\hline 52 & Barbados & $\mathrm{BRB}$ & 496 & Mongolia & MNG \\
\hline 112 & Belarus & BLR & 499 & Montenegro & MNE \\
\hline 56 & Belgium & BEL & 500 & Montserrat & MSR \\
\hline 84 & Belize & BLZ & 504 & Morocco & MAR \\
\hline 204 & Benin & BEN & 508 & Mozambique & MOZ \\
\hline 60 & Bermuda & BMU & 104 & Myanmar & MMR \\
\hline 64 & Bhutan & BTN & 516 & Namibia & NAM \\
\hline 68 & $\begin{array}{l}\text { Bolivia } \\
\text { Bosnia and }\end{array}$ & BOL & 520 & Nauru & NRU \\
\hline 70 & Herzegovina & $\mathrm{BIH}$ & 524 & Nepal & NPL \\
\hline 72 & Botswana & BWA & 528 & $\begin{array}{l}\text { Netherlands } \\
\text { Netherlands }\end{array}$ & NLD \\
\hline 76 & $\begin{array}{l}\text { Brazil } \\
\text { British Virgin }\end{array}$ & BRA & 530 & $\begin{array}{l}\text { Antilles } \\
\text { New }\end{array}$ & ANT \\
\hline 92 & $\begin{array}{l}\text { Islands } \\
\text { Brunei }\end{array}$ & VGB & 540 & Caledonia & NCL \\
\hline 96 & Darussalam & $\mathrm{BRN}$ & 554 & New Zealand & NZL \\
\hline 100 & Bulgaria & BGR & 558 & Nicaragua & NIC \\
\hline 854 & Burkina Faso & BFA & 562 & Niger & NER \\
\hline 108 & Burundi & BDI & 566 & Nigeria & NGA \\
\hline 116 & Cambodia & KHM & 570 & Niue & NIU \\
\hline 120 & Cameroon & CMR & 574 & $\begin{array}{l}\text { Norfolk Island } \\
\text { Northern } \\
\text { Mariana }\end{array}$ & NFK \\
\hline 124 & Canada & CAN & 580 & & MNP \\
\hline
\end{tabular}




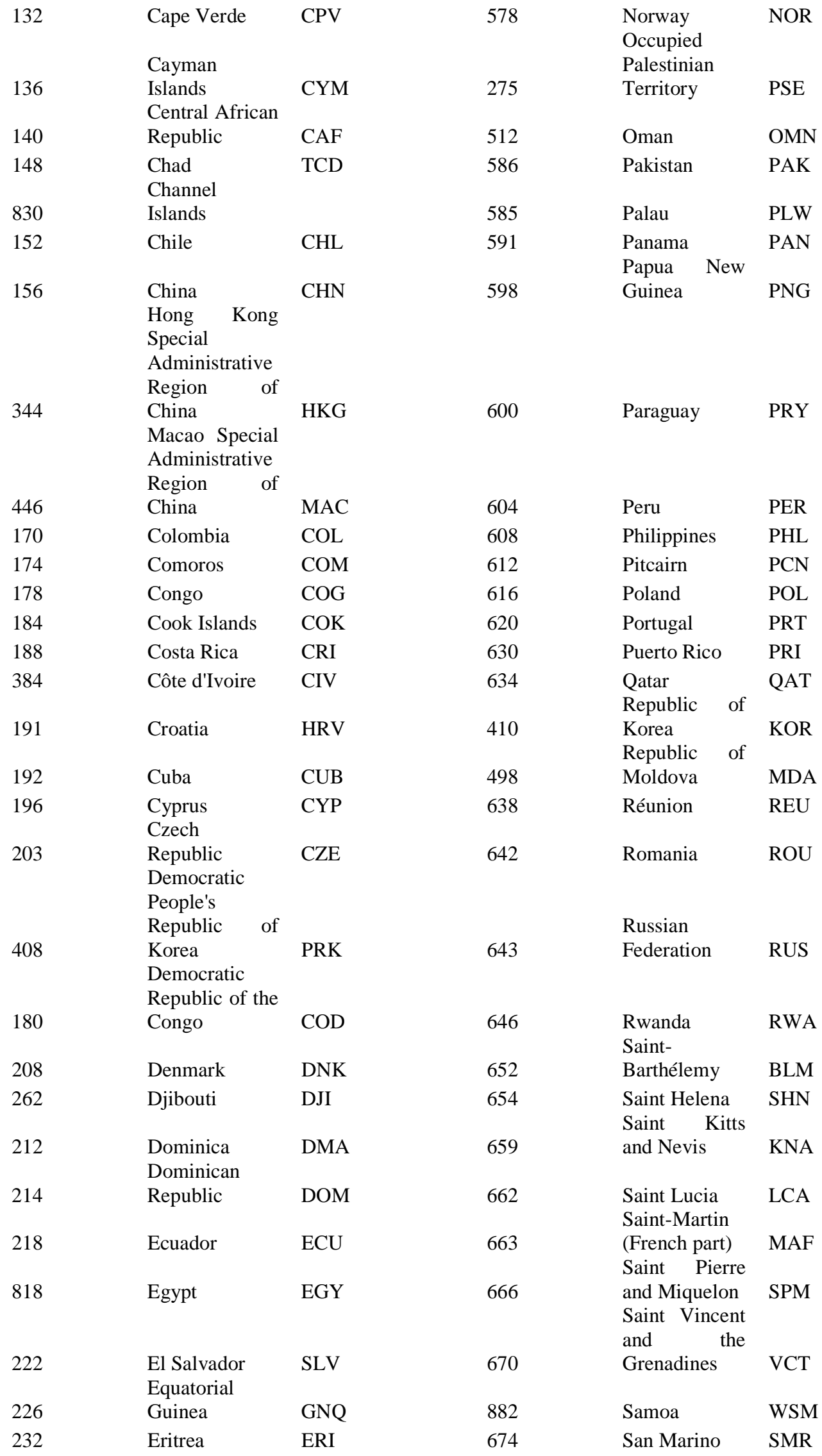




\begin{tabular}{|c|c|c|c|c|c|}
\hline 233 & Estonia & EST & 678 & $\begin{array}{l}\text { Sao Tome and } \\
\text { Principe }\end{array}$ & STP \\
\hline 231 & Ethiopia & ETH & 682 & Saudi Arabia & SAU \\
\hline 234 & $\begin{array}{l}\text { Faeroe Islands } \\
\text { Falkland } \\
\text { Islands }\end{array}$ & FRO & 686 & Senegal & SEN \\
\hline 238 & (Malvinas) & FLK & 688 & Serbia & SRB \\
\hline 242 & Fiji & FJI & 690 & Seychelles & SYC \\
\hline 246 & Finland & FIN & 694 & Sierra Leone & SLE \\
\hline 250 & France & FRA & 702 & Singapore & SGP \\
\hline 254 & $\begin{array}{l}\text { French Guiana } \\
\text { French }\end{array}$ & GUF & 703 & Slovakia & SVK \\
\hline 258 & Polynesia & PYF & 705 & $\begin{array}{l}\text { Slovenia } \\
\text { Solomon }\end{array}$ & SVN \\
\hline 266 & Gabon & GAB & 90 & Islands & SLB \\
\hline 270 & Gambia & GMB & 706 & Somalia & SOM \\
\hline 268 & Georgia & GEO & 710 & South Africa & ZAF \\
\hline 276 & Germany & DEU & 724 & Spain & ESP \\
\hline 288 & Ghana & GHA & 144 & Sri Lanka & LKA \\
\hline 292 & Gibraltar & GIB & 736 & Sudan & SDN \\
\hline 300 & Greece & GRC & 740 & $\begin{array}{l}\text { Suriname } \\
\text { Svalbard and } \\
\text { Jan Mayen }\end{array}$ & SUR \\
\hline 304 & Greenland & GRL & 744 & Islands & SJM \\
\hline 308 & Grenada & GRD & 748 & Swaziland & SWZ \\
\hline 312 & Guadeloupe & GLP & 752 & Sweden & SWE \\
\hline 316 & Guam & GUM & 756 & $\begin{array}{l}\text { Switzerland } \\
\text { Syrian Arah }\end{array}$ & CHE \\
\hline 320 & Guatemala & GTM & 760 & Republic & SYR \\
\hline 831 & Guernsey & GGY & 762 & Tajikistan & TJK \\
\hline 324 & Guinea & GIN & 764 & $\begin{array}{l}\text { Thailand } \\
\text { The former } \\
\text { Yugoslav } \\
\text { Republic of }\end{array}$ & THA \\
\hline 624 & Guinea-Bissau & GNB & 807 & Macedonia & MKD \\
\hline 328 & Guyana & GUY & 626 & Timor-Leste & TLS \\
\hline 332 & Haiti & HTI & 768 & Togo & TGO \\
\hline 336 & Holy See & VAT & 772 & Tokelau & TKL \\
\hline 340 & Honduras & HND & 776 & $\begin{array}{l}\text { Tonga } \\
\text { Trinidad and }\end{array}$ & TON \\
\hline 348 & Hungary & HUN & 780 & Tobago & TTO \\
\hline 352 & Iceland & ISL & 788 & Tunisia & TUN \\
\hline 356 & India & IND & 792 & Turkey & TUR \\
\hline 360 & Indonesia & IDN & 795 & Turkmenistan & TKM \\
\hline 364 & $\begin{array}{l}\text { Iran, Islamic } \\
\text { Republic of }\end{array}$ & IRN & 796 & $\begin{array}{l}\text { Turks and } \\
\text { Caicos Islands }\end{array}$ & TCA \\
\hline 368 & Iraq & IRQ & 798 & Tuvalu & TUV \\
\hline 372 & Ireland & IRL & 800 & Uganda & UGA \\
\hline 833 & Isle of Man & IMN & 804 & $\begin{array}{l}\text { Ukraine } \\
\text { United Arab }\end{array}$ & UKR \\
\hline 376 & Israel & ISR & 784 & $\begin{array}{l}\text { Emirates } \\
\text { United } \\
\text { Kingdom of } \\
\text { Great Britain }\end{array}$ & ARE \\
\hline 380 & Italy & ITA & 826 & and Northern & GBR \\
\hline
\end{tabular}




\begin{tabular}{|c|c|c|c|c|c|}
\hline & & & & $\begin{array}{l}\text { Ireland } \\
\text { United } \\
\text { Republic of }\end{array}$ & \\
\hline 388 & Jamaica & JAM & 834 & Tanzania & TZA \\
\hline 392 & Japan & JPN & 840 & $\begin{array}{l}\text { United States } \\
\text { of America } \\
\text { United States }\end{array}$ & USA \\
\hline 832 & Jersey & JEY & 850 & Virgin Islands & VIR \\
\hline 400 & Jordan & JOR & 858 & Uruguay & URY \\
\hline 398 & Kazakhstan & KAZ & 860 & Uzbekistan & UZB \\
\hline 404 & Kenya & KEN & 548 & $\begin{array}{l}\text { Vanuatu } \\
\text { Venezuela } \\
\text { (Bolivarian }\end{array}$ & VUT \\
\hline 296 & Kiribati & KIR & 862 & Republic of) & VEN \\
\hline 414 & Kuwait & KWT & 704 & $\begin{array}{l}\text { Viet Nam } \\
\text { Wallis and }\end{array}$ & VNM \\
\hline 418 & Republic & LAO & 732 & Sahara & ESH \\
\hline 428 & Latvia & LVA & 887 & Yemen & YEM \\
\hline 422 & Lebanon & LBN & 894 & Zambia & ZMB \\
\hline 426 & Lesotho & LSO & 716 & Zimbabwe & ZWE \\
\hline 430 & Liberia & LBR & & & \\
\hline
\end{tabular}

